\title{
Lu Xun and the Crisis of Figuration
}

"No fanciful sagas, now," they warned. "We're not here for a good time or to nurture new literary talent. Make up a story, and you'll wish you hadn't."

Policemen to Fang Yan in Wang Shuo's Playing for Thrills

One might say ... that the practice of confession creates the metaphors of innerness that it claims to explore: without the requirement of confession - one might overstate the issuethere might be nothing inward to examine. In other words, the very notion of inwardness is consubstantial with the requirement to explore and examine it.

Peter Brooks, Troubling Confessions

\begin{abstract}
u Xun embodies many of the paradoxes of the past one hundred years of Chinese literature. Long accepted as the most important writer of the modern (xiandai) period following 1917, he was also extremely active in the cultural activities of the final decade of the Qing, which he spent mostly in Japan. ${ }^{1}$ Being born in 1881 meant that his life straddled the great transformations that have been examined in the earlier chapters of this book. He was, however, born a good deal later than most of the figures analyzed in the earlier chapters of this book, and, as we saw in chapter 8, the pressures militating against maintaining an always fragile balance between ideas perceived as indigenous and those perceived as imported had grown stronger as he entered his career as a story writer. But the era of his birth also afforded him the distinct perspective of being remarkably conversant in both the Western and the Chinese intellectual traditions, in a way that even one so painstakingly self-educated as $\mathrm{Yan} \mathrm{Fu}-\mathrm{a}$ full generation older-could never approach. Lu's extraordinary learning and profundity of insight caused him to be regarded as a key member of the radical reformers gathered around New Youth almost from the moment
\end{abstract}


he reluctantly enlisted in their ranks in 1918. He was, however, also virtually unique among the group of mostly younger radicals of that period in holding on to the "jindai ethos" and expressing significant misgivings about the nature and the process of reform from the very outset of his participation.

As his parable of China as an iron room from which there is no escape would indicate, ${ }^{2}$ much of this reluctance to participate stemmed from his fear that any movement for comprehensive change was bound to fail in the end. Past commentators have, however, paid far too little attention to the possibility that a crucial part of his foot-dragging may have been rooted in a sense that, given the characteristic dispositions of both the reformers and their opponents, even if victory were to be achieved and change duly brought about, the victory would prove in the end to have been Pyrrhic and the change far from what was hoped for. Because Lu Xun was very familiar with writing from and about the West, his skepticism about the applicability of borrowed ideas to China is in its own way every bit as thoroughgoing as that of the late Qing novelists or even Zhu Shouju.

In a review of Lu Xun's first collection of stories published in October 1923, two months after the book appeared, the critic Shen Yanbing (Mao Dun) noted the exceptional variety of its contents: "In the Chinese literary arena, Lu Xun is often the vanguard in creating 'new forms'; of the dozen or more stories in Nahan (Call to arms), almost every one is written in a new form." ${ }^{3}$ Given the sense of the crisis facing China that Lu Xun felt, his restless experimenting with the short story form should be seen as part of his effort to come to grips with a difficult situation rather than as an exercise in pure aesthetics. This is not at all to deny his commitment to his art, but rather to emphasize the complexities involved in his struggles to represent and thereby somehow bring to resolution the most vexing questions of his time. In fact, as his negative remarks on the late Qing novel in his history of Chinese fiction illustrate, he was mindful of what he regarded as the artistic failures of that set of narratives, and his relentless search for formal innovation may well have represented an anxious attempt to escape from those flaws as he set out to write stories of his own.

As had been the case with Yan Fu's realm of ideas and with Wu Jianren's narratives, among Lu Xun's stories and essays are many that work out numerous notions and modes of writing that have clear antecedents or, at least, counterparts in the West. In his struggle to shape these modes of figuration ${ }^{4}$ to his own purposes, Lu Xun left innumerable traces that show how the linguistic and imaginative resources at hand, even at their best, could still not enable him to work out a vision of past, present, and future that was anything other than a source of ongoing torment. This is, again, not to gainsay Lu Xun's aesthetic achievement or the sophistication 
of his understanding of the materials he was working with, but ultimately merely to point out his inability to be satisfied with his own efforts-perhaps no writing of any sort could accomplish what he hoped to accomplish with it. This chapter will explore Lu Xun's deployment of some of his most significant literary figures and tropes and will attempt to show at least a portion of his intellectual struggle in trying to bring them to bear on a stubbornly resistant contemporary situation.

\title{
The Years in Japan
}

Lu Xun's remarkable series of four early essays, written toward the end of the period he spent studying in Japan, already gives voice to an exceedingly pessimistic mood. In his influential "On the Power of Mara Poetry" of 1908, he explains the heroic quality of the European poets of resistance he has labeled the "Mara School," a name taken from the Hindu goddess of destruction and indicating a kind of satanic power. Then he concludes:

\begin{abstract}
Now survey China: Where are the warriors of the spirit? Is there a genuine voice to lead us to goodness, beauty, and vigor? Is there a warm voice to deliver us from this barren winter? Barren homeland, without a Jeremiah to compose a final lamentation as a legacy to the world. Unborn perhaps, or murdered by the public, or both - thus China has become desolate. Only for the body have great pains been taken, while the mind faded into the barrens; the onslaught of the new overwhelmed it. "Reform," said the public, a voice that confessed its habitual wrongdoing, as if to say, "We repent." Along with reform came the birth of hope; as we expected, scholars introduced modern culture. But after a decade of incessant introduction, consider what they've been coming back with: nothing, aside from how to manufacture cake and guard prisons. In China, perennially desolate, a second call for reform is virtually certain yet to come, given past history. 5
\end{abstract}

With this utterance, Lu Xun sounds a characteristic late Qing note ${ }^{6}$ that can be traced back to Liang Qichao's first article advocating the utility of the novel, which was published in 1898 and is discussed in chapter 4 . Although Lu Xun has announced the power of heroic literature over the course of his essay, he concludes by lamenting the virtual absence of such a literature from China (at least since the demise of Qu Yuan two thousand years before). The root cause of this absence seems to be a lack of strong, individual voices capable of delivering the sort of jeremiad that could overcome a profound inertia.

For all the pessimism that $\mathrm{Lu}$ Xun voices here, equally significant is his apparent confidence-based, no doubt, on his firm conviction of 
the ineluctability of social evolution - that "a second call for reform" is bound to come, sooner or later. Presumably this new call for renewal will be vitally dependent upon a literary activism set in motion by an awakened set of individual voices. Such activism is easy to assume, given his view that reforms restricted to the material realm - as embodied in his mordant summary of that realm as "manufacturing cake and guarding prisons" - could not lead to any substantial improvements. There is every reason to believe that Lu Xun during his time in Japan regarded literature as the basic vehicle for any such spiritual reform, even if we consider only the retrospective account of his activities and development there in his 1922 preface to Call to Arms: "[I]t doesn't really matter how many of [the people of a poor and backward country] die of illness. The most important thing for us is to change their spirit, and since the best thing to change the spirit was of course (or so I thought at the time) literature, I therefore thought to promote a literary movement." 7

This sense of a need for a new departure is expressed even more clearly in "On Cultural Extremes" ("Wenhua pianzhi lun"), an essay published shortly before "Mara Poetry." In the former article, Lu Xun extensively and approvingly cites nineteenth-century European thinkers like Ibsen, Kierkegaard, Nietzsche, and Stirner in support of an activist spirituality. Lu Xun argues that late Qing China had been misled by the fallacious idea that fundamental reform could be brought about by attending only to the material and utilitarian externals of nineteenth-century European economic development. He couples this to what Lung-kee Sun has called a "proto-modernist" idea - that the true genius of modern Europe lies in notions of radical individualism advanced by the thinkers Lu Xun cites to counter the all-pervasive materialism brought about by economic growth. ${ }^{8}$ A persistent denunciation of materialism and mass society in favor of a notion of the vital role of a transcendent individual subjectivity runs insistently through the whole text of "Cultural Extremes": "Only those who are resolute and steadfast, and who can remain unmoved even when they encounter external [obstacles] can provide anchors for society ... [and the enervated masses] can look to [such] men of determined will to provide the core of leadership in the future." 9 This praise for the power of subjective judgment brings about a consequential contempt for the meager competence of the crowd. After citing the public condemnation of Brutus and Christ as examples, for instance, Lu Xun concludes, "Therefore, right and wrong cannot be adjudicated by the masses; any adjudication by the masses will bring about incorrect results. [Neither] can political affairs be adjudicated by the masses, for their standards are inequitable and will not lead to happy results." 10

There can be little doubt that Wang Hui is correct about this essay when he writes, "Lu Xun takes the structure of subjectivity as the only 
basis for his historical critique of society; he thereby takes the individual subjective consciousness as the foundation for the blueprints of his plans for national and social liberation." " For all the rhetorical flourish that $\mathrm{Lu}$ Xun brings to bear in this essay, however, a number of obvious contradictions protrude from the deceptively smooth surface of the discourse. The most glaring reveals itself in his conclusion that, should the reformist attitudes he advocates be adopted in China, "the people of our nation will attain self-awareness, their individuality will flourish, and this country that is now a heap of loose sand will become a nation of true human beings." 12 What could have been the source of this sudden ability of the entire population to gain the sort of awareness that Lu Xun had previously viewed as the exclusive property of the discerning few? There seems to be here a slippage here between what Wang Hui has identified as two quite distinct strains of individualism: that which regards all individuals as equal and that which stresses the rights of particular persons. ${ }^{13}$ At the end of his essay Lu Xun appears to conflate the two, evidently generalizing the Nietzschean notion of rights pertaining to the superior individual to the whole population of a reimagined China. In the final analysis, perhaps, Lu Xun seems unable to bring himself to limit possession of the liberated subjectivities he describes in such fine detail to a specific subset of Übermenschen.

Part of the contradiction between the divergent ideas of individuality here can probably be best explained by resort to the weak sense of the ontological position of the individual in the Chinese revolutionary discourse of the time. For instance, Zhang Binglin, Lu Xun's acknowledged teacher and probably the leading radical voice of the day, had in October 1907 published an article in Minbao, a Japan-published journal of the contemporary revolutionaries, that touched upon the question of the status of the individual. Although the main point of this influential essay was to deconstruct the intellectual authority of the notion of the state by questioning its existence as an substantial entity, Zhang moves on, almost as an afterthought, to an analysis of the position of the individual in a cosmology heavily indebted to Buddhist ideas:

One might ask: Given this [i.e., that all things other than atoms are constructed of smaller elements], since humans are also constituted of a combination of cells, how can they be said to have their own essential natures (zixing)? In response, strictly speaking, humans must also be called only factitious entities (weiwu). In discussing humans in relation to one another, however, then they are all in a position of provisionality (jiayou), and one cannot dismiss one provisional entity from the standpoint of another. If, on the other hand, the cells of one's body were to brazenly insist that humans were provisional, then a human would not 
be in a position to refute this thesis. But in dealing with the nation-state (guojia), the entity (ziti) [dealing with it] is not another nation-state but is rather a human vis-à-vis a nation-state. And while humans are factitious entities, they are rather simple (danchun) ones. In comparison with composite groupings [like nation-states], then, [humans] approach the [status of] the genuine (zhen).14

Lu Xun's conviction of the illegitimacy of mass groupings was most probably influenced by Zhang's insistence upon the nonorganic nature of large political bodies, and both of the writers insist upon the right of the individual agent to offer a critique. In so readily allowing that the individual ultimately has no substantial ontological status, however, Zhang necessarily undermines the speaking position he is ostensibly advocating. In other words, a strong sense of individual agency is validated only in contrast to larger, even falser agglomerations, like the state. Thus any attempt at creating a powerful notion of individual agency must eventually run up against Zhang's confession that the self is not a constant entity. While this may seem a relatively minor concession on Zhang's part as he proceeds to undermine the power of the nation, when Lu Xun finds himself needing to construct a powerful notion of individual agency, the contradictions cannot, perhaps, be so readily set aside. If nothing else, this helps explain Lu Xun's paradoxical reluctance to set himself up as an individual authority, a reluctance that can be discerned even in his writings produced during his years in Japan and even more strongly in the years that followed.

This temporizing with the authority of individual agency is apparent even in the basic compositional mode of "Cultural Extremes": throughout a long piece of writing in praise of the power of the individual, Lu Xun almost never phrases any of his advocacy in his own voice. In the course of the essay, whenever he explains the rise of the powerful individual in Europe, he invariably cites Ibsen, Nietzsche, Stirner, or some other European as the authority for the perception. For instance, the full context of the passage quoted above is as follows: "Therefore, right and wrong cannot be adjudicated by the masses; any adjudication by the masses will bring about incorrect results. [Neither] can political affairs be adjudicated by the masses, for their standards are inequitable and will not lead to happy results. Only with the appearance of the Übermensch (chaoren) will the world achieve its greater order (taiping)" (emphasis added). ${ }^{15}$ This final invocation of the superman reminds the reader that Lu Xun has not been directly presenting his own opinion but rather has been developing an argument of Nietzsche's in the preceding page of extremely dense classical prose.

The constant resort to the voice of Western authority here lends a 
certain irony and distance to what otherwise seems intended as not just a powerful statement of opinion but as a call for resolute action as well. Is there not more than a little irony lodged in the fact that this series of affirmations of the power of the subjective voice is almost never presented as issuing from the consciousness of the writing subject himself? In other words, there is inscribed here more than a little of the reserve and doubts about expressing strong views that come to be such prominent features of a number of Xu Lun's writings from the May Fourth period. Perhaps we can also see here, represented as clearly as we are likely ever to find it, the imbedded anxiety about adopting the voices of another historical tradition as one's own.

The careful structure of quotation built up here and the underlying tentativeness of address serve as constant reminders of Lu Xun's awareness of the foreignness of his sources. He clearly believes these voices speak to what the times demand, but he also seems determined to keep them at some distance, for which there may be yet another reason. The sense that the late Qing advocates of material reform had become possessed and emboldened by the ideas they sought to emulate runs strongly throughout Lu Xun's essay. In thus keeping the European at arm's length, he is perhaps also on guard against the possibility of becoming locked up in a new totalism of subjectivity as potentially dangerous as the one he is speaking against. Naoki Sakai has summarized Takeuchi Yoshimi's fundamental realization about Lu Xun: "[R]esistance has to be likened to a negativity, as distinct from negation, which continues to disturb a putative stasis in which the subject is made to be adequate to himself." 16

\section{The New Era}

The new call to cultural reform that Lu Xun had anticipated did eventually come, seven years later, with the Chen Duxiu's founding of Qingnian zazhi-a journal notable for its focus on the need for a new individual consciousness - in Shanghai in September 1915. The iconoclasm that followed, in its determination to completely reformulate the horizon of Chinese thought, proceeded rather rapidly to simply deny the legitimacy of anything from within the intellectual regimes of the past. The radical voices that came to dominate the new journal were intent not so much upon denouncing any particular thinker or pattern of thought as they were upon announcing the theoretical impossibility of finding any validity or nuance in anything that had come before. Thus the Xin qingnian writers would have had to regard the elaborate moral nuance and awareness of the intense difficulty of choices that permeate the writings of Yan Fu, Zhang Binglin, and the early Lu Xun, if anything, as symptoms of the dread inertia of the old ways rather than as signs of serious men- 
tal engagement. One example of Chen's impatience with any hesitation can be found in his in late 1915 contrast between the European determination to engage in struggle as opposed to China's peaceable nature. $\mathrm{He}$ notes the efforts of the small nations of Belgium and Serbia at the beginning of World War I to resist much larger opponents, adding: "Their strength of character in resisting difficulty may be looked upon as a descent into madness by East Asian peoples; but if we could imitate them in even in the tiniest way, would the inferior (liedeng), peace-loving, serenitypromoting, harmonious, and elegant East Asian peoples have fallen into the conquered position they occupy today?" 17 The radical force of the polemic of iconoclasm in the magazine was set out in some detail in chapter 8 and needs no further discussion here.

By 1918 Lu Xun had begun to publish, in Xin qingnian itself, writing in response to this radical call of 1915. The thoroughgoing iconoclasm of Chen and even the rather more thoughtful appeals of Lu Xun in 1908 can be seen, however, to have become muted by an undefined anxiety. The resulting hesitation is rendered most explicitly toward the end of $\mathrm{Lu}$ Xun's late 1922 introduction to his first collection of stories:

So I finally agreed to write something for [Qian Xuantong/Jin Xinyi], and the result was my first story, "Madman's Diary." From that time on, once started I could not stop writing, and I would compose a short story-like piece to dispose of the entreaties of my friends (yi fuyan pengyou de zhutuo) until after a time I had more than a dozen of them.

For my part, I thought I had long ceased being the kind of person who feels any great urge to express himself. ${ }^{18}$

It seems evident here that Lu Xun's hesitation had by this time extended itself even to the matter of whether he should write or not. It is not hard to see this as the logical outcome of the paradoxical combination of a firm conviction about the power of literature and a weak sense of his own individual agency as revealed in his hesitancy in 1908. Nevertheless, this reluctance stands in such stark contrast to the deliberate stridency of his peers as to suggest that new factors were involved.

The question of what occasioned this new sense of vacillation about the act of writing has over the years given rise to a good deal of speculation in the scholarship on Lu Xun. Lin Yu-sheng, for instance, in The Crisis of Chinese Consciousness set out the idea of a barely suppressed reservoir of commitment to the old morality. This created "a sense of guilt arising from the tension between two incompatible intellectual and moral commitments." ${ }^{19}$ Marston Anderson in The Limits of Realism, on the other hand, argues that the Chinese literary world of the May Fourth period had an extravagant expectation regarding the powers of the newly im- 
ported literary idea of realism. Whereas for most of the writers of the "New Literature" this merely reinforced a predisposition to suffuse their work with a sense of political mission, in Lu Xun it occasioned a fine moral hesitation concerning the extent to which a writer has the right to represent human suffering. ${ }^{20}$ In other words, if realism has the power to, as it were, legislate a new order, how far may a writer go in replicating in his created world the cruelties arising from the vicious stratifications of the old order?

In China a crisis in values followed the great reorientation of intellectual horizons after 1895, including an increased attention to Buddhist ideas. Given the essential fragility of the notion of personal identity that resulted, it is probably not surprising that a Lu Xun who was at least a decade older than the vast majority of those who began writing fiction after 1917 would remain tentative in the presentation of his own voice. Moreover, the effusion of subjective excess that marked some of the firstperson narratives in the upsurge in novel production after 1902-such as the 1906 Qinhai shi (Stones in the sea), by Fu Lin, and the 1913 Huangjin sui (The money demon), by Chen Diexian (1879-1940) ${ }^{21}$ - would have made (and did make) any serious writer wary of the dangers of literary self-indulgence.

A full reckoning of the ways in which Lu Xun's uncertainty manifested itself in narrative practice, however, has yet to be made. It is one thing to rely on the voices of others in announcing a general worldview as Lu Xun did in 1908, but in confronting the need to construct an entirely new set of fictional worlds, it is not so easy to take refuge in the constructs of other writers. I would thus argue that at virtually every level of narrative figuration Lu Xun was confronted with-or, perhaps more accurately, confronted himself with - an acute crisis of legitimization. In short, the combination of a tentative sense of the range of the individual voice, combined with a new notion of the power of narrative representation, created for Lu Xun a particular sort of hesitation when it came to the construction of his short stories.

In brief, the specific figural crisis I am referring to here consists of a systemic instability of the relationship between the means of constructing a piece of narrative and its possible referents in the social life of the period. Given the dual pressures of the general sense of fiction's authority, which dates back to Liang Qichao's writings after the failure of the 1898 reforms, and the fact that writers were caught up in the very social uncertainty they were trying to remedy, certain questions inevitably came up: would, for instance, writing in a certain way about society and the people living their lives within it have a kind of legislative power to reify the conditions being written about? If so, even if the author intended a critique of those social conditions, what moral burden did he assume by writing them up in certain ways? If, however, one was to assume that the novel 
could bring about dramatic social change, one had also to allow the form a wide-ranging power to intervene in social life. And what were some of the deeper implications of this notion for Lu Xun and his narratives?

This general crisis of signification makes itself felt at any number of levels in Lu Xun's stories. There are several narrative elements where the resulting impasse becomes definitive in shaping the author's fictional oeuvre, and they serve to contrast some of Lu Xun's narrative modes with Western ideas concerning narrative. One of these alternative avenues can be traced by examining an idea Peter Brooks develops in his important narratological work, Reading for the Plot. At one point in that work, Brooks, following Walter Benjamin, notes that "the meaning of a life cannot be known until the moment of death: it is at death that a life first assumes transmissible form - becomes a completed and significant statement - so that it is death that provides the authority or 'sanction' of narrative." 22 It is not hard to see the application of this idea to numerous instances in the Western novel. In the particular discussion at hand, Brooks takes Conrad's Heart of Darkness as his primary example. In that work, the structural importance of Kurtz, his death, and his deathbed vision of the "Horror" is something everyone knows well. The unremarkable nature of the structural imperative contained in Kurtz's demise is reflected in the fact that even to suggest some complicity in it or a sense of bad faith by the narrator Marlow (or the implied author behind him) can, as far as I know, be found nowhere in the extensive critical canon devoted to Conrad's novel.

It is precisely on a point almost identical to this, however, that $\mathrm{Lu}$ Xun places the main focus of his moral inquiry in a number of his narratives, or at least those in Panghuang (Hesitation), his second collection of stories, published in 1926. As Anderson has noted, the most prominent stories in this gathering feature "ironical mediating narrators" who "allow Lu Xun to posit the opening of a full critical examination of the social order and to explore its consequences." ${ }^{23}$ In those works built around the death of a key character - almost invariably someone who is victimized by the normal workings of a cruel society and is, more often than not, a woman, by the way - the moral gnashing of teeth surrounding that death, as Anderson has noted, is extraordinary. As the summary remarks of the narrator in "Zhufu” (The new year's sacrifice) would indicate, Lu Xun certainly takes these deaths as foundational elements in the stories in which they take place. For at the very moment in the story when the narrator satisfies himself that Xianglin Sao is, after all, better off dead, he says: "At this point, however, the fragments of her life that I had heard and seen before that linked themselves up into a whole piece." 24

As is equally clear from the story, Lu Xun also seems to respond to the idea of death as a structural imperative of narrative with an unmistakable shock and horror. His personal disinclination to see people sac- 
rificed is expressed eloquently in a letter he wrote in 1925 to Xu Guangping (1898-1968), Lu Xun's former student and eventual partner, when he cites one of the grounds he assumes disqualifies him for a role in political leadership as "I am most unwilling to allow others to be sacrificed." 25 His stories bother themselves to the point of obsession with the question of moral responsibility for these deaths. Again and again these texts raise the disturbing question of whether the narrator/author will have to bear responsibility for killing someone off in order to become able to narrate that person's life with real authority. A constellation of issues hovers around each narrated death: how can one even entertain the possibility of the need for these deaths? Why would one have to? And, at the core, what might be the reasons for this sense of presumptive guilt? If nothing else, these questions contrast sharply with the ones Brooks raises about Heart of Darkness, which are all concerned with mimetic fidelity, as for instance: "The [key] question may then be whether Marlow can tell the story 'right' the second time around: whether the story that needs telling can properly be told at all, since proper telling may imply a conventional semantics and syntax that are unfaithful to Marlow's experience of Kurtz's experience of the heart of darkness." ${ }^{26}$

Karl Kao has pointed out that the key to the differences between the sort of issue Brooks focuses on and the obsessions one can locate within Lu Xun's narratives might be found in different epistemologies underlying the European and Chinese linguistic and literary traditions:

Within the Chinese framework, where language presents the person (vs. represents the world) and knowledge is intended for moral efficacy (vs. for the definition of truth), reflexive issues could hardly be expected to be riveted on the question of mediation or the "relationship of fictionality to reality." With respect to both the premises of the expressive (presentational) theory and the pragmatic orientation of epistemology, the problematic will more likely turn up in the area concerned with the relationship of word and deed, with the moral and ideological implications of the agency. 27

In this light it is perhaps no surprise that in Lu Xun's stories the question of whether the story can be told (and told faithfully) recedes before the question of whether it should be told, given the cruelties it will be obliged to body forth. The moral center of each story involving a character's death seems inevitably to return the focus to the morality of the narrator himself and then to the implied author behind the narrator. In other words, how much blame must the implied author take upon himself for giving finality to a particular construction of worldly facts by stipulating them to be so in his narrative? With this in mind, the concluding lines 
in "Guxiang" (My old home)-lines that critics have almost universally taken as the very emblem of possibility - may thus have a more sinister implication: "[Hope] is just like roads across the earth. For actually the earth had no roads to begin with, but when many people pass one way, a road is made." ${ }^{28}$ In a China in flux between new and old, creating images of possibility through narrating them into being seems to embody the risk of actually bringing any number of monstrous creatures of the imagination closer to actuality. In one of Lu Xun's last short stories, "Shangshi" (Regret for the past), Juansheng contemplates shucking himself of the "burden" imposed upon him by his relationship with Zijun, a relationship he had exerted every effort to bring into being in the first place. Juansheng's elaborate fantasies underline the unsettling possibilities inhering in the imagination:

Icy needles pierced my soul, sentencing me to a persistent, numbing pain. Life still held out many roads to me (shenghuo de lu hai henduo), and it came to mind that I still had not forgotten how to move my wings - the thought of her death suddenly occurred to me, but I immediately reproached myself and repented.

Sitting in the public library, I could often make out a ray of hope, as a new road for my life stretched out before me: she would bravely come to an awareness of the situation and resolutely depart this wintry home ... . 29

In this chilling passage, the fearful destruction implicit in bringing the new into existence is virtually explicit, and it is linked ineluctably with death.

Thus, the narrator in many of Lu Xun's more important stories presents himself with a terrible choice. He may either "kill off" the old-and, he cannot help perceive, the people who inhabit that realm - by writing it (and them) off as something that urgently needs to be superseded. Or he may give the old regime continued life and thereby risk perpetuating it and denying the "second call for reform" that Lu Xun had looked to with such certainty in 1908. As Tsi-an Hsia wrote in his profound study of $\mathrm{Lu}$ Xun's morbid attitudes, "In his public utterances and creative writings, $\mathrm{Lu}$ Hsün did not seem to be so much horrified by death itself as by death as the symbol of a bygone age." ${ }^{0}$ I would suggest, however, that it is the combination of the awful moral responsibility of having to "perform" death in narrative and the sense of death as symbol of overturning the weight of the past that confers upon death the particular intensity it has in Lu Xun's stories. In light of this, the absence of the subjective voice in "Cultural Extremes" suddenly seems as though it was the only way a younger $\mathrm{Lu}$ Xun could express ideas so prospectively disturbing. In speaking through 
others, Lu Xun could put off, for a time at least, taking a highly discomfiting personal responsibility for ideas that were ultimately to yield such devastating social consequences. In creating narratives, however, this responsibility for creating an individual voice to express his opinions could no longer be deferred.

Lu Xun never directly represents either the conflicting perspectives behind this omnipresent guilt in his stories or the China/West split that is a key feature underlying it. There is throughout the corpus of these texts, however, an unmistakable and pervasive sense of disconnect between the modern authorial/narratorial consciousness and other mentalities, necessarily of an earlier time, with whom he comes into contact. And as was so clear in the sharp debates outlined in chapter 8 , "modern" means "Western" here, which was also the way the radicals of the May Fourth era overwhelmingly continued to define it. The emblem of this disconnect is the native who returns after so long that he feels himself to have no home; an automatic distance is established between him and everyone he meets, who are so carefully marked as also being remembered from earlier times. The writing voice is driven at once to anatomize these others, so as to understand why they have not or cannot become like him, but he is simultaneously tortured by a guilt that his act of anatomizing is a kind of murder. But whence, one may ask, comes this personal sense of guilt? Is not the "murder" actually the work of the cruelties and inadequacies of the old society? While the politically minded critic or ordinary reader may be content with this answer, the author/narrator constantly bothers himself about the nature of his implication within the old dispensation. In other words, as separate as he feels himself to be from the past, is he not bound to it in ways he cannot even begin to understand? And, in sorting through Lu Xun's conflicts here, one cannot, as with Yan Fu before him, pass over the complex exigencies of seeking refuge from the uncertainties of modernity in some sort of nationalistic identity, even as the substance of that identity must largely be denied.

Before consigning the figure of death to simply being the specter of guilt, however, we must first deal with "Ah Q zhengzhuan" (The true story of Ah Q). In that longest of Lu Xun's stories, the miserable eponymous main character can achieve consciousness only at the moment of his own death - a clown unexpectedly given the chance to "peep over the edge" and perceive of meanings he had never so much as imagined before. Even as he is presented with this insight, however, he is given no chance to make use of or even fully to process mentally what he sees at that moment. This marks the terrible inscription of the necessity and pathos of the death of the old. It lies at the point of juxtaposition of the horror that Ah Q suddenly can see, his inability to make out anything from it, and the final narrated inconsequence of his existence. Can there be any 
redemption in this? If so, what might redemption mean, and could it ever be worth the price? In Lu Xun's 1926 account of how the story came to be written, he seems to express the contradictions embodied in the character in the way he remembers how he decided to finish him off. One moment he seems to take the whole matter quite casually: "After about two months' work on [the story], I really felt like ending it, but I really can't remember clearly ... [ [how I ended as I did]." Soon thereafter, however, he hints at a darker purpose: "Actually, the 'grand reunion' was not conferred upon him so casually as all that." ${ }^{11}$ In other words, death retains its sting even in a setting that Lu Xun seems to be doing his best to render farcical.

There are thus dilemmas inhering in any possible representation of attitudes toward the past, as well as in the impossibility of avoiding the creation of painful nodes of plot in writing fiction. Given such dilemmas, one might think that the best way out of it would be to fashion ambiguous situations or narrators who temporize by steadfastly putting off any decision at all and thereby allow for a dispassionate examination of all the possible alternatives. Indeed, as I suggest above, this can arguably be taken as Lu Xun's motive in hiding behind the words of others in "Cultural Extremes." In the narrative world of Lu Xun, however, the moral demands of narrative seem to oblige a more direct confrontation of all major issues that are broached. In two of his most important stories, "New Year's Sacrifice" and "Zai jiulou shang" (In the wineshop), for instance, the dramatized narrator in each text quite explicitly avoids commitment by refusing to choose between two highly fraught possibilities. Ironically, this failure to choose is presented to the reader as the most cowardly and wrong of what turns out to have been three choices all along. This weak third option, whose craven nature is revealed only at the end of each story, presents itself as being vastly the worst thing to do in any possible moral universe.

In "Wineshop," for instance, Lü Weifu, the self-pitying old friend of the unnamed principal narrator, turns out in the end to be in effect shoring up the old by teaching material that was central to the curriculum of traditional education. The reader eventually understands, however, that Lü's behavior is far superior to the opting out of any commitments at all on the part of the primary narrator, whose smirking sense of superiority to the earnest Lü casts him in the worst possible moral light. The similarly unnamed narrator in "New Year's Sacrifice," while on the surface apparently taking a role of little consequence in the demise of Xianglin Sao, nonetheless manages to convince the reader of his culpability. More than anything else, this effect results from the fervency with which he repeats his denials that the poor woman has any moral claim on him whatsoever. The ultimate transparency of the falsity of his denial is most clearly revealed in his final expression of the conviction that she is better off dead anyway: "[T]hose who enjoyed life must have wondered at her for wish- 
ing to live on; but now at last she had been swept away by death. Whether spirits existed or not I did not know; but in this world of ours the end of a futile existence, the removal of someone whom others are tired of seeing, was just as well for both them and for the individual concerned." ${ }_{2}$

The irony in this statement stands out brutally even in its subtlety. By voicing statements that seem virtually identical to the thoughts of the people in the text whom he had initially found morally horrifying, the narrator reveals himself to be trapped between the near ineluctability of drawing such conclusions and the full dread of actually having done so. A famous passage from Heart of Darkness invokes a similar sort of irony: "The conquest of the earth, which mostly means the taking it away from those who have a different complexion or slightly flatter noses than ourselves, is not a pretty thing when you look into it too much. What redeems it is the idea only. An idea at the back of it; not a sentimental pretence but an idea; and an unselfish belief in the idea-something you can set up, and bow down before, and offer a sacrifice to." ${ }^{33}$ By invoking the theretofore unthinkable notion that the noble ideas undergirding the imperialist enterprise are as fetishistic as any of superstitions it was pleased to think of itself as eradicating, Marlow suddenly reveals the full horror of colonialism: its cruelty is exceeded only by its hypocrisy. Even as he comes to this realization, however, Marlow at no point in this disquisition hints at any complicity on his own part. He maintains an independent position as detached observer, a secure subjectivity able to keep its distance from the horrors he observes going on around him. In "New Year's Sacrifice," on the other hand, Lu Xun's narrator exposes his own conscience as being finally no less concerned with his personal psychic comfort than were the inhabitants of the village from whom he had sought to distinguish himself in all ways for most of the story. At no point does he give any indication that he realizes the implication of his remarks for the position of superiority vis-à-vis the town's inhabitants that was an article of faith for him at the beginning of the story. Marlow, in other words, stands outside events as he passes negative judgment, a position Lu Xun's narrator is never permitted to achieve.

Guilt about one's role in manipulating characters caught in unfortunate circumstances, so evident in the treatment of Xianglin Sao, is one thing, but a similar anxiety about the propriety of creating utopian visions in general seems less easy to understand. This is especially true when one considers that, while external factors govern the dystopian regime that occasions authorial resistance, the utopian vision that would lie opposite to it would be, by definition, something arising finally out of authorial interiority, a zone that in Western narrative writing has generally been represented as an area of considerable freedom. Lu Xun, however, ap- 
pears to bring to this particular subjective function the same sense of caution that he brings to other manifestations of the individual voice. The extraordinary manipulation of the working of memory in "My Old Home" presents the clearest case of this. To begin with, the most striking thing about the utopian longing that suffuses this text is its composition in a mode one would not expect to find in a literature of iconoclasm: instead of voicing hope for the future, utopianism in this story is expressed as a longing for a vanished past, which invariably presents itself to the narrator as incomparably superior to the fallen present.

The distance between the two is, in fact, at first represented as an agonizing difficulty in recalling the exact nature of those prior days. As the narrator says to himself while drawing near his native place after an absence of twenty years: "The hometown I remember is not like this at all. My hometown was better by far. But if you ask me to recall its beauty or to speak of its good parts, I have neither any images nor any words to express them." 34 Eventually his mother's mention of Runtu, someone he recalled from childhood, brings the memories flooding back with vivid definition: "Right then, a marvelous picture suddenly flashed into my mind: a round, golden moon suspended in a deep blue sky and under it the sandy verge of the sea . ..."35 Upon having this recollection, he sums up his feelings: "Now that my mother mentioned his name, it suddenly rekindled all my memories in a single flash, and it seemed as if I were able to see my beautiful home." 36 Immediately thereafter, however, he encounters "Bean-curd Beauty," another person from his past, but in this case someone he had not remembered at all until she rudely reminded him of her existence. The narrator's lapse of memory brings about a distinctly unpleasant meeting, for she draws bitter attention to his failure, as well as to the sociological implications of one of his status ignoring someone of hers.

This momentary dose of reality fades away with the news that Runtu has arrived at the narrator's house. The narrator looks forward to this reunion with the greatest of anticipation, but when the two actually meet, they are both tongue-tied, at least until Runtu breaks the ice by recognizing the narrator as "Master" (laoye). This decisive declaration of social difference sends a shiver through the narrator, closing off once again the possibility of recalling the beauty of his old home. At the end of the story, hope is rekindled for a third time in the narrator's mind, this time while he is on the boat heading back to the city. The comfort on this occasion comes to him through his consideration of the possibility that the next generation might not fall victim to the cruelties of life in the same way that he and Runtu had. Given the disappointment that each earlier access of hope had brought about, however, the narrator immediately recoils from the impulse, saying to himself, "When I thought of hope, I suddenly be- 
came afraid." ${ }_{37}$ The disappointments that arise out of the collisions between his nascent optimism and the ways of the world eventually seem to oblige the narrator to regard hope as a reckless subjective indulgence.

In short, each utopian projection, however foreshortened, is immediately stymied by an abrupt encounter with a bitter reality that renders any prospect for the implementation of change exceedingly remote. The ways in which the historical Lu Xun shared these anxieties about utopian projections with the narrators in his stories hardly needs to be remarked upon. ${ }^{38}$ The complex examination of the possibilities and pitfalls of memory in "My Old Home" can be taken as a transparent metaphor of the author's own process of representing his own subjectivity. The devastating disillusion that overcomes that story's narrator each time he allows positive memories full play in his mind surely provides a privileged insight into the nature of the reservations Lu Xun expressed about committing himself to the act of writing narratives based on attempts at individual confession.

Authorial awareness of the delusions inhering in confessional writing has often been noted by critics. For instance, as J. M. Coetzee has said of what he takes to be Dostoyevsky's views on this matter as expressed in The Idiot, "Because of the nature of consciousness . . . the self cannot tell the truth of itself to itself and come to rest without the possibility of self-deception." ${ }^{39}$ As Peter Brooks has commented on this process, Dostoevsky himself envisioned but one way out of the impasse thus created: "faith and grace ..., punishment, penance, and ultimately . . redemption." Brooks goes on to ask: "But about a world, or a writer, for whom faith and grace are not viable concepts? Is the confessional discourse without faith and grace condemned to being nothing but the sterile, unending unmaskings of the underground 'paradoxicalist'?" 40 Whether Lu Xun was aware of the comforts of the notion of divine grace is impossible to say, but it is probably safe to assume that even had he learned of them, he would have regarded them as illusory at best. ${ }^{41}$ The fearful possibility of a sterile and unending cycle of confession and introspection, on the other hand, seems to torment him at every step of the way in the creation of his first-person narratives.

In the most general sense, Lu Xun's bleak vision of social alienation may at first glance seem familiar enough to the modern audience. Georg Lukács, for instance, in his early Theory of the Novel proposes that the novel form itself uniquely embodies a sense of the dissolution of a prior social totality: "[I]n all other genres . . . affirmation of a dissonance precedes the act of form-giving, whereas in the novel it is the form itself." 42 One can readily see how such an analysis might seem tailor-made for a story, told from a modern perspective, of an inability to reconstruct a past that has receded hopelessly out of reach, like "My Old Home." As Paul de Man 
long ago pointed out, however, Lukács's vision of formal dissonance is ultimately redeemed by a sense of the power of time to embody the meaning that has been lost, something that seems to be explicitly ruled out in Lu Xun's writings: ${ }^{43}$

This victory is rendered possible by time. The unrestricted, uninterrupted flow of time is the unifying principle of the homogeneity that rubs the sharp edges off each heterogeneous fragment and establishes a relationship-albeit an irrational and inexpressible one-between them. Time brings order into the chaos of men's lives and gives it the semblance of a spontaneously flowering, organic entity. . . . Beyond events, beyond psychology, time gives [the characters in novels] the essential quality of their existence ... [and] cancels out the accidental nature of their experiences and the isolated nature of the events recounted. ${ }^{44}$

If I may sidestep for the moment the question of the general validity of Lukács's notion of the function of time in the novel, it does seem safe to say that it is precisely such moments of transcendental temporal fusion that Lu Xun cannot bring himself to embrace. To cite only the case of Ah Q's sorry demise and the infinitesimal moment of enlightenment that preceded it, here Lu Xun almost sadistically mocks the notion of any salvation offered by the expanse of time. If Lukács's assumption of the redemptive power of time depends upon a sense of its inexhaustible supply, the fearful brevity of Ah Q's moment of consciousness demonstrates just how little time Lu Xun felt he had to work with. It is as if he is squeezed between a stagnant China and a (Western) modernity advancing rapidly into the future, in which the rush of time, rather than offering ultimate redemption, is itself the major source of anxiety. If calling attention to this fact is painful for Lu Xun, he stills feels it imperative to create a sharp and unbridgeable temporal break between the present and the past so as to be able to represent China's predicament. In short, however much he might have wished to invest reminiscence with a wealth of feeling, Lu Xun's evident sense of that past's dysfunctionality caused him in his hard fictional world to suppress any romantic musings like those of Lukács on the healing powers of time.

Lu Xun's experience is perhaps shared by intellectuals caught up in the squeeze between their natural affections for their home cultures and the pressures to "modernize" exerted by the example (and/or coercion) of the West. It is striking, for instance, how closely the musings of Indar, the tormented Oxbridge-educated East African Indian of V. S. Naipaul's powerful novel of postcolonial dislocation, A Bend in the River, parallel those of the narrator of "My Old Home." Indar speaks to Salim, his much less-educated friend of youth, in regard to coping with one's feel- 
ings about the past: "YYou [must eventually] stop grieving for the past. You see that the past is something in your mind alone, that it doesn't exist in real life. You trample on the past, you crush it. In the beginning it is like trampling on a garden. In the end you are just walking on ground. That is the way we have to learn to live now. The past is here.' He touched his heart. 'It isn't there.' And pointed at the dusty road." 45 Of particular interest here is the contrasting parallel with the image that concludes "My Old Home." Whereas the narrator of Lu Xun's story speaks wistfully of trampling out new paths upon the earth where nothing had existed before, Indar is more forthright in seeing through to the inevitable demolition of any and all historical memory that must inevitably be a part of this move. In other words, the very past that at so many junctures of the story holds out the only possible source of comfort for the narrator must be ruthlessly paved over, both from Indar's perspective and from that of "Brother Xun" himself.

But for all the clarity with which Indar realizes what he must do, through the course of the novel he, like Brother Xun, can never succeed in tying himself off from memories that continue to call to him of a "beautiful home." Salim's practical-minded fiancée, Kareisha, describes Indar's torment, in the final time that Indar's name is mentioned in the text:

“... He [Indar] had got a simple idea. The idea was that it was time for him to go home, to get away.

"And that's how it has been with him. From time to time that is all he knows, that it is time for him to go home. There is some dream village in his head. In between he does the lowest kind of job. He knows he is equipped for better things, but he doesn't want to do them. . . He doesn't want to risk anything again. The idea of sacrifice is safer, and he likes the act." 46

Aside from the uncanny resemblance of this description to the character of Lü Weifu in "In the Wineshop," the passage also discloses a curious contradiction, which is that, for all his fixation upon his "dream village," Indar is, by birth and upbringing, a third-generation resident of an East African city. He can thus have no concrete memory of any actual village in which he has ever resided. Kareisha actually seems unclear even as to which continent this village might be on: is it in the East African country that is his natal place or the India that is his ancestral homeland? Although Indar can talk more boldly of the need to trample on the past than Lu Xun's narrator, they are both obsessed by recurrent visions of a utopian space. In Indar's case, however, the torment is perhaps rendered the more acute by his utopia's being purely the product of his imagination. He is, on the other hand, never subject to the disenchantment of the 
actual that befalls the narrator in "My Old Home" upon his revisit to the actual place that had inspired his nostalgia.

\section{The Madman and His Discontents}

If traumatic encounters with the imperialistic West form the evident material ground of both Heart of Darkness and A Bend in the River, the actual presence of specific references to the West are scarce in Lu Xun's narrative work. As I have attempted to argue, however, the figural presence of the West and its new ideas spectrally hovers over the construction of each of Lu Xun's stories. Only in "Kuangren riji” (Madman's diary) - Lu Xun's first story published in Xin qingnian in 1918 and conventionally regarded as the first work of the New Literature of the modern era-does the image of the West become considerably more palpable, though in the end it remains only an abstraction. It is nonetheless an abstraction that carries an immense discursive weight, being all the heavier precisely because of the vagueness of the reference to it. The embedded nature of the "absent cause" of an anxiety occasioned by the coming of the West is even more striking when the basic material of the story is taken into account: it is, as J. D. Chinnery has observed, a narrative built on a careful awareness of the behavior of a clear schizophrenic, the sort of character who would not generally overlook any potential source of threats to his person. ${ }^{47}$

"Madman's Diary," told in diary form in thirteen mostly short segments following a brief introduction by a friend of the diary's writer, develops as an extended metaphor of the cruelty of traditional Chinese society. Taking as its central image the figure of cannibalism, the story clearly marks itself as a highly critical account of the Chinese past, but one formulated as being immanent within the tradition itself. All specific references in the text-from the mention of history books as being everywhere overwritten by "virtue and morality" (renyi daode) to the invocation of figures from Chinese history and the classics, like Yi Ya, a man of antiquity who purportedly cooked up his own son to indulge his lord's culinary curiosity, and the famous pharmacologist Li Shizhen (1518-1593) are to indigenous events and persons. Even the references to $\mathrm{Xu} \mathrm{Xilin}$, a revolutionary anarchist executed in 1907, and to "four thousand years of history" serve to specify the story and to bring it down almost to the date of its composition.

The narrative's move into an evolutionary discourse in section 10, however, suddenly hints at a set of ideas beyond the ken of the local framework of the earlier sections. The narrator underscores this reference when he admonishes his older brother: "Brother, probably all barbaric peoples (yemande ren) ate some human flesh in the beginning. Later, because their ideas changed, some stopped eating human flesh and, being intent on 
improving themselves, changed into humans, real humans (zhende ren)." 48 The diary's writer then compares to beasts (chongzi) those who have "refused" to take this step, and thereby sharpens the contrast between the "real humans" and all others. The diarist goes on to draw his conclusion from an obvious social Darwinian point of view, including the following general appeal:

"You can effect a change, a change issuing from sincerity. You must realize that in the future the world will have no place in it for those who eat human flesh.

"If you don't change, then you will all devour one another. And if a number of you are still alive, you will be extinguished by the real humans, just as wolves have been exterminated by hunters, just as it was with beasts!" 49

Much of the power of the allegory contained within this story, at least to begin with, stems from the generally unambiguous metaphorical referents set out as the story develops: Chinese history has over its great length disguised its predatory nature with false expressions of morality, and anyone - in this case, the "madman" himself- who has the temerity to point out the obvious will be threatened with the most extreme ostracism. Indeed, as Wang Xiaoming has noted, Lu Xun is generally inclined to be obvious about the meanings of the figures he employs:

[The symbolic figures just enumerated] are clearly purposeful designs, each one as clear as can be and instantly recognizable for what they are meant to suggest. At times the author seems to be afraid his readers will not understand the point, so he intentionally emphasizes the symbolic meaning of such figures. For instance, at the beginning of "The Eternal Lamp," he uses such inflated language to introduce the various hermetic characters that it is clear that he is pointing out to you that they epitomize the morbidly flawed Chinese people. He even uses narratorial comments as footnotes, as at the end of "My Old Home," where he is at pains to disclose the motive behind Runtu's taking away of the incense burner. If we can say that, in general, novelistic symbols issue from a powerful lyrical impulse on the part of the author, the symbols issuing from Lu Xun's pen are just the opposite, demonstrating just how deeply rationality imposes itself upon his emotions. 50

The invocation of the "real humans," however, complicates this scheme by abruptly revealing the debt the general allegory bears to these spectral beings: their entry on the scene retrospectively reveals that what seemed at the outset to be a critique on strictly indigenous terms had 
all along been sanctioned by an implicit contrast with these more highly evolved others. The question then arises as to who these beings represent: is the allegorical scheme one in which humans in general are being compared with some superior ideal? Or is the scheme one in which the historical Chinese are contrasted with an equally historical set of more highly evolved people, in this case inevitably the same Western people from whom emanated the theory of evolution that sets the tenor of these final segments of the story?

The specificity of the rest of the allegorical scheme would argue in favor of the latter interpretation over the former, which, however, does not end the questions posed by this enigmatic text. For instance, was, then, modern Chinese literature-and the variety of new styles and modes brought into being to convey it - set in motion by an act of the most devastating invidious comparison? And are the terms of this contrast so powerful as to necessitate that all subsequent writing fall within its shadow, as Frederic Jameson's much-maligned essay on the omnipresence of "national allegory" in Third World literature would suggest? ${ }^{51}$ As fundamental as these questions are, the deliberate vagueness of the diarist at this juncture in his text combines with the surplus of narratorial anxiety engendered by the overwrought tone of the story to render these issues as continuing sources of worried inquiry rather than as moments leading toward closure.

The interiority opened to the reader through these diary entries, a form universally signifying introspection, is drawn back relentlessly to analysis of the social terms on which it is based. It is as if the author will not allow himself the indulgence of wallowing in bootless rounds of selfexamination, afraid from the beginning that there might be nothing there to discover. This forestalled interiority can be fully appreciated only by comparing Lu Xun's segment with the concluding section of the tale of a Russian madman by Nikolai Gogol, the namesake of Lu Xun's story. In Gogol's concluding entry, the narrator has a fantasy of escaping from the earth and sees a montage of scenes as he departs. He finally focuses on a particular house and asks: "And isn't that my mother sitting by the window? Mother, save your wretched son! Let your tears fall upon his sick head! See how they torture him! Hold me, a poor waif, in your arms. There's no room for him in this world. They are chasing him. Mother, take pity on your sick child...." 52 The reference to the scene of the pietà here could not be more obvious; the promise of redemption offered by the mother suggests the divine overtones of the image, the same divine grace, in other words, that Brooks sees Dostoevsky falling back upon to provide ultimate salvation for his tortured characters.

Images of extermination of those who can't or won't keep up with the "real humans" haunt the final segments of Lu Xun's story: the fear and 
shame of the implications of modernity manifest themselves all the more powerfully for their having been muffled in tentative forms of representation. Thus, at the beginning of his short career as an author of narrative fiction, Lu Xun constantly signifies the quandaries inhering in the form he has chosen: the foreign origin of the problematics he finds himself involved with is a primary source of tension, and that tension is amplified by the structural inability to tie these elements into a unity that can definitively shape the questions themselves, much less provide any definitive answers. While these difficulties function like grains of sand caught in an oyster and lead to spectacular narrative results, the results themselves are constructed so as to offer continual reminders that the process of literary creation set in motion by these irritations was enabled only by real pain. 